University at Buffalo School of Law

Digital Commons @ University at Buffalo School of Law

Journal Articles

Faculty Scholarship

Winter 1-1-2018

\title{
Renouncing Citizenship as Protest: Reflections by a Jewish Israeli Ethnographer
}

Irus Braverman

University at Buffalo School of Law

Follow this and additional works at: https://digitalcommons.law.buffalo.edu/journal_articles

Part of the Anthropology Commons, and the Sociology Commons

\section{Recommended Citation}

Irus Braverman, Renouncing Citizenship as Protest: Reflections by a Jewish Israeli Ethnographer, 44 Critical Inquiry 379 (2018).

Available at: https://digitalcommons.law.buffalo.edu/journal_articles/910

\section{(c) (i) (9)}

This work is licensed under a Creative Commons Attribution-NonCommercial 4.0 International License. This Article is brought to you for free and open access by the Faculty Scholarship at Digital Commons @ University at Buffalo School of Law. It has been accepted for inclusion in Journal Articles by an authorized administrator of Digital Commons @ University at Buffalo School of Law. For more information, please contact lawscholar@buffalo.edu. 


\section{Renouncing Citizenship as Protest: Reflections by a Jewish Israeli Ethnographer}

\section{Irus Braverman}

Renunciation is liberation. Not wanting is power.

It is with a newfound clarity of thinking and analyzing a very emotional tragedy that I have thrown off the shackles of Zionist propaganda and am proudly and publicly renouncing my Israeli citizenship effective immediately.

-Lenny Lapon, retired school teacher, Springfield, Mass. ${ }^{2}$

Few Israelis have renounced citizenship, but an estimated one million10 percent of the population or so- - have chosen to live abroad. Are we doing covertly what Lenny Lapon did openly? When driving home from a concert, my two daughters, then five and seven years old, insisted that I tell them why I had left Israel more than ten years before. I stumbled-how to explain this to them? Why did I leave Israel? The easiest thing would be to tell them what everyone thought then-that I traveled for my doctorate. But that was not the entire truth; when I left, I already knew that this was not a temporary move. I was leaving for good.

How did that decision come to be? I grew up in a typical Zionist household. My mother survived the Holocaust - most of her family didn't; my father's immediate family escaped to Israel from Europe just before World War II. For my family, Israel was a refuge, the difference between life and death.

I would like to dedicate this article to Harry George Segal.

1. Quoted in Jacqueline N. Font-Guzmán, "Asserting Puerto Rican Identity by Legally Renouncing U.S. Citizenship," Centro Journal 25 (Spring 2013): 23.

2. Lenny Lapon, "Renouncing My Israeli Citizenship," Mondoweiss, 21 July 2014, mondoweiss.net/2014/07/renouncing-israeli-citizenship 
My military training was a painful eye-opener. I was educating soldiers about the City of David when the first Intifada broke out in December 1987. I was trapped in the old aqueduct (Nikbat HaShiloah) by enraged Palestinians who tossed stones down. I was perplexed; why did they hate us so much?

After that, the questions kept coming. The more I studied about Zionism (the version presented to me in my military training, that is), the more I questioned it. By the third year of my service, I was recording atrocities against Palestinians with my camera and was even beaten up once by a fellow soldier while documenting an incident near Hebron. In the years that followed, I worked with various nonprofit organizations, including the Israeli ACLU, where I had volunteered during my law school years. I also volunteered with Machsom Watch, a women's organization documenting Israeli Defense Forces (IDF) conduct at checkpoints. After four years of weekly visits to the checkpoints, I came to realize that any sort of resistance is easily coopted into Israel's all-encompassing occupation regime. It seemed like there was no way out of being part of the oppression except to stop living in this place altogether. More than anything else, I wanted to shed the burden of everyday privileges that have accompanied my identity as a Jewish Israeli citizen.

Still, and even more so after I left, it was important for me to write about the occupation as a form of resistance to it. Over the next few years, I visited Israel for fieldwork and used my privileges as a Jewish Israeli, combined with an ethnographic methodology, to expose the role of the Jewish National Fund in appropriating Palestinian lands and the related processes of politicizing nature, the transformation of the checkpoints, the ecological imperialism implicit in the interrelations among three zoos in Israel/Palestine, and the meaning of captivity in the dehumanization of Gazans. ${ }^{3}$

3. See Irus Braverman, Planted Flags: Trees, Land, and Law in Israel/Palestine (New York, 2009), "Civilized Borders: A Study of Israel's New Crossing Administration," Antipode 43 (Mar. 2011): 264-95, "Animal Frontiers: A Tale of Three Zoos in Israel/Palestine," Cultural Critique 85 (Fall 2013): 122-6, and "Captive: Human and Animal Life in Gaza," Public Culture 29 (Jan. 2017): 191-215.

Irus Braverman is Professor of Law at the University at Buffalo, State University of New York. Her most recent monograph, Wild Life: The Institution of Nature (2015), draws on interviews with 120 conservation professionals and activists to explore core dilemmas of wildlife conservation. Braverman's current project, Coral Whisperers: Scientists on the Brink (forthcoming 2018), explores the emotional and professional challenges facing coral scientists in today's political and physical climate. Her email is irusb@buffalo.edu 
Exactly ten years after leaving Israel, the siege on Gaza of August 2014 marked a watershed divide in my relationship to the State of Israel. I realize that my trauma is insubstantial in comparison with the tens of thousands of Gazans who have lost their loved ones and homes, but in August 2014 I felt like I lost my home too.

The events of summer 2014 and the painful realizations that they invoked have led me to consider renouncing my Israeli citizenship. Contemplating what may seem like a straightforward stance of resistance, I have come to realize how complex it actually is. This short essay considers renunciation as an act of protest from the standpoint of a Jewish Israeli legal ethnographer and geographer.

Since I am an ethnographer-a methodology that entails in-depth interviews and direct observations_obtaining access is key for my research. The privilege of being an Israeli Jew, I realized, is a double-edged sword in that it provides access that is both dreaded and desired. On the one hand, this access is founded upon and reliant on Israel's apartheid regime; on the other hand, it is precisely through the privileging schemes of this regime that I have obtained the trust of and justified my access to military officials and courts, Jewish settlers and settlements, officials from the Jewish National Fund, and government institutions and archives-access that has been instrumental for my fieldwork.

How would renouncing my citizenship affect this access? Would I be increasingly limited to performing Skype ethnographies rather than in-person interviews and observations? Until now, the only Skype ethnography I conducted was of Gazan interviewees; as a Jewish Israeli I am denied entry into Gaza, as well as into Area A of the West Bank (although the latter illegality has been easier to work around). One way or the other, I don't recall any of my interviewees ever asking about my formal citizenship, so perhaps it matters less than my personal identity? But while I may be able to renounce my formal citizenship, it would be much harder if not impossible to renounce my personal identity and the occupier's privileges that attach to my Jewish Israeli name, my language and accent, and my specific demeanor, social networks, and insider knowledge. If I cannot renounce the substantial privileges that come with my personal identity, what meaning would a formal renunciation of my citizenship have as a form of protest, and what would it mean for my work?

It is interesting how inseparable identity and citizenship often appearas if they are synonymous - and yet the statist logic is actually quite recent. Renouncing my citizenship would not entail the abandonment of all that makes up my identity - if it did, resistance would become a hollow act, as it depends precisely on that identity that is resisted. At the same time, renun- 
ciation as protest can only be meaningful if it entails a certain sacrifice of personal identity. The fact that this decision is so emotionally difficult for me indicates that it does entail such a sacrifice. Indeed, I still feel a sense of belonging to the Israeli people and a strong connection with this place, where I breathed, walked, dreamed, loved, worked, and resisted for the first thirty-four years of my life.

And what if renouncing my Israeli citizenship would in fact benefit my work and scholarship_-would this take away from the power of rejecting citizenship as protest? With the Palestinian boycott of Israeli institutions and the semiformal boycott of Israelis from certain Palestinian spaces gaining force and traction, renouncing my Israeli citizenship, while possibly closing certain doors, may indeed open others. Such changes would potentially impact my choice of research topics too. Another professional consideration is the legitimacy of my research. From the point of view of many Jewish Israelis, radical critique is only acceptable (although less and less so) from within; everyone else is suspected of anti-Semitism. In the summer of 2014 my parents told me that because I don't live in Israel, I no longer have the right to criticize it - an argument that is often sounded against diaspora Jews.

Then there are the pragmatic, and bureaucratic, considerations. How to actually renounce my Israeli citizenship? And, perhaps more importantly, how to prevent this act from being a mere technicality, a submittal of forms to the Israeli Ministry of the Interior for a fee of ninety-two dollars, ensuring that it remains a political statement that is open, inspiring even, for others? The right to and the determination of citizenship vary among different national contexts. What interests me here is the approval by the state of an individual's voluntary renunciation of citizenship, especially when performed as an act of protest against this state.

Puerto Rico is one example in which citizenship renunciation has been utilized as a statement of resistance toward colonization and occupation. After losing the Spanish-American War, Spain turned Puerto Rico, Guam, and the Philippines over to the United States in 1898. Puerto Rico's formal status then became, and still is, that of an unincorporated territory of the United States. As a result of complex legal layering, Puerto Rican citizenship coexists with US citizenship, subjecting Puerto Ricans to federal legislation and Supreme Court decisions but not granting them voting rights. In 1994, after the federal courts denied his request to renounce his US citizenship, Jose "Fufi" Santori Coll led a group of 250 Puerto Ricans in a symbolic renunciation of their US citizenship. ${ }^{4}$ They were then issued Puerto Rican

4. See Santori v. United States, 30 F.3d 126 ( $1^{\text {st }}$ Cir. 1994). 
passports, also known as Fufiportes. Although these were not recognized as valid international travel documents, some Puerto Ricans used them as such. At this point, the US informed other governments that allowing Puerto Ricans to travel on Fufiportes would be interpreted as an unfriendly act. At around the same time, Puerto Rican independence activist and lawyer Juan Mari Brás renounced his citizenship. This time, the federal government approved the request and Mari Brás was issued a Certificate of Loss of Nationality, one of only two issued to Puerto Rican renouncers. Soon after, however, the State Department reversed its prior approval. Based on a Supreme Court ruling that was handed down shortly before, the State Department now argued that Mari Brás's choice to live in Puerto Rico proved that he did not want to give up his US citizenship. ${ }^{5}$

This brief overview foregrounds the following questions: aren't all modern states founded upon bloodshed? And, if so, shouldn't all citizens be renouncing their citizenship? Or from the opposite angle: why bother replacing one flawed citizenship with another? In my own case, how is my current US citizenship better than the Israeli one that I am considering renouncing? What, if any, is a citizen's responsibility vis-à-vis her nation-state(s), and how far back does this responsibility go? As a citizen of the United States, am I now responsible for slavery? For the war in Iraq? For the continued oppression of people of color and the ongoing colonization of Puerto Rico? And does this responsibility change if I hold double or even multiple citizenships? Maybe because I just acquired my US citizenship, I don't really consider myself an American and haven't (yet?) felt the need to take on the responsibilities that come along with this citizenship. In any case, the renunciation of citizenship as protest cannot be a renunciation of responsibility to redress injustice, a shedding of liabilities; it is, rather, a taking on of enhanced responsibility, an act of care.

Despite the significant differences between the two contexts-indeed, Puerto Rican renouncers share more in common with Palestinian citizens of Israel-I am inspired by the Puerto Rican example to consider the renunciation of Israeli citizenship as a performance of protest. Israeli law requires that renouncers hold a dual citizenship (itself a privileged status_-in my case directly linked to my identity as a scholar, as I acquired my US citizenship through my academic institution). ${ }^{6}$ Yet renunciation as protest

5. See Lozada Colón v. U.S. Department of State, 2 F. Supp. 2d 43, 45-46 (D.D.C. 1998), and Jacqueline N. Font-Guzmán, Experiencing Puerto Rican Citizenship and Cultural Nationalism (New York, 2015), pp. 76-77.

6. See "Renouncing Israeli Citizenship," Israel Ministry of Foreign Affairs, mfa.gov.il/MFA /ConsularServices/Pages/Renouncing_Israeli_citizenship.aspx. The case of Mordechai Vanunu is one instance in which Israel refused to approve renunciation. 
needn't be officially recognized by the state. In the Puerto Rican example, renouncers had no recognizable second citizenship, which made their utilization of renunciation as a means of protest that much sharper. Many Israelis who reside in Israel and have no other citizenship could do the same, and their renunciation would, similarly, be rejected by the State of Israel. The power of protest is arguably strengthened in the face of its legal impossibility.

In Israel, citizenship can be acquired in several ways. As an important element of Israel's Zionist ideology, its 1950 Law of Return grants every Jewish person a right to live in Israel and obtain citizenship (extended in 1970 to people of Jewish ancestry and their spouses). From 1995 to 2009, 2,734,245 Jews immigrated to Israel. ${ }^{7}$ In a letter published by The Guardian in 2002, forty-four British nationals renounced their right of return in solidarity with Palestinians, ${ }^{8}$ and in 2003 more than one hundred American Jews in San Francisco similarly renounced their automatic right to immigrate to Israel in protest of Israel's refusal to extend the same right to Palestinians. ${ }^{9}$ Although I haven't been able to obtain any figures for renunciations of Israeli citizenship as protest, it seems safe to say that of the reported cases, the majority of renunciations were of the right of return rather than of active citizenships by Jewish Israelis. ${ }^{10}$ Avigail Abarbanel, Dror Feiler, and Gilad Atzmon are examples reported by the media of nativeborn Israelis who, after residing abroad and establishing citizenship there, have renounced their Israeli citizenship in support of the Palestinian cause. ${ }^{11}$ I couldn't trace many others. Perhaps it is because dual citizenships aren't that easy to come by that the reported cases about Jewish Israelis renouncing their citizenship (rather than Jewish nationals of other states renouncing their right of return) are few and far between? Does this absence of in-

7. See "Inside the Jewish Agency," The Jewish Agency for Israel, www.jewishagency.org /insideja

8. Letter, The Guardian, 8 Aug. 2002, www.theguardian.com/theguardian/2002/aug/o8 /guardianletters4

9. "Jews Renounce Right to Israeli Citizenship," Al Jazeera, 3 Oct. 2003, www.aljazeera .com/archive/2003/10/20084109275184799.html. See also Lapon, "Renouncing My Israeli Citizenship."

10. In 2005,808 Israelis applied to the Ministry of Interior to renounce their citizenship, compared to 740 requests in 2004 and 561 in 2003; see Relly Sa'ar, "Number of Israelis Renouncing Their Citizenship Rises 44\%," Haaretz, 26 Dec. 2005, www.haaretz.com/news/number -of-israelis-renouncing-their-citizenship-rises-44-1.177491

11. See "Biography of Avigail Abarbanel," www.avigailabarbanel.me.uk/biography.html, and Michelle Malka Grossman, "Israeli on Flotilla Ship to Gaza: I Am Doing This for the Israeli People," Jerusalem Post, 24 June 2015, www.jpost.com/Arab-Israeli-Conflict/Israeli-on -ship-to-Gaza-I-am-doing-this-for-the-Israeli-people-406975. For Gilad Atzmon, see "Bio," Gilad Atzmon, www.gilad.co.uk/bio/ 
formation indicate rarity, or is it evidence of institutional erasure? Perhaps it is easier for Israel to quietly grant such requests without inquiring into their particular merits so as to evade public discussion about protest?

Israel has been much more reluctant to release its Palestinian citizens, however. For example, in 2003 the Israeli Foreign Ministry was "shocked" to learn that the Federal Court of Appeals in San Francisco granted a Palestinian citizen of Israel political asylum in the United States, relying on the State Department's statement that there "definitely can be tension, and beyond, at the local level between Israeli Arabs and Israeli Jews" (a similar petition by a Mizrahi Israeli refusenik was denied in 2012 by Canadian courts). ${ }^{12}$ Ironically, while it fantasizes about a Palestinianless existence, Israel at the same time clings to its Palestinian citizens as evidence of its democratic elitism and is angered when this image is challenged-which further highlights the crucial differences between renunciation by the privileged and by the oppressed.

What is the power of not wanting, of excluding oneself, and how does it compare with resistance when performed from within the state? We are familiar with strategies of civil disobedience such as conscientious objection to mandatory conscription and Thoreau-style refusal to pay taxes. Multiple paths also exist for resisting the Jewish privileges bestowed by the Israeli State from within. A 2011 decision by the Tel Aviv District Court that granted the prominent Israeli novelist Yoram Kaniuk's request to erase the classification "Jewish" from his identification card is worth considering in this context. Kaniuk's renouncement was of his official, not his personal, Jewish identity, he insisted. He refused to be part of a "Jewish Iran," in his words. ${ }^{13}$ A prior petition to Israel's Supreme Court by thirty-eight prominent Israelis to order the Minister of Interior to register them as "Israeli" rather than "Jewish" was rejected. The State's position was that such registration would undermine Israel's very existence. These legal decisions demarcate the boundaries of legitimate insider discussions about national identity in contemporary Israeli society. ${ }^{14}$

For me, the crucial difference between working from inside versus outside of Israel has been my overwhelming sense that every act of resistance

12. "Israel Checks How an Arab Israeli Received Political Asylum in the US," Haaretz, 16 July 2003, www.haaretz.co.il/misc/1.896300. And see "Refusenik Petitions for Political Asylum in Canada," Haaretz, 14 July 2012, www.inn.co.il/News/News.aspx/241037

13. Mazal Mualem, "Israeli Author Yoram Kaniuk Asks Court to Cancel His 'Jewish' Status," Haaretz, 15 May 2011, www.haaretz.com/print-edition/news/israeli-author-yoram-kaniuk -asks-court-to-cancel-his-jewish-status-1.361720

14. See Yuval Yoaz, “The State Attorney's Office: Registration of an 'Israeli' Nationality on an Identity Card Undermines the State," Haaretz, www.haaretz.co.il/misc/1.96739o 
from within is subsumed by the hegemonic Zionist narrative. I was also not willing to continue living out the privileged everyday blindness toward the occupation. Admittedly, not being physically present in Palestine/Israel has made it increasingly difficult to keep up with the ever-changing expressions of oppression, alongside the mushrooming acts of protest, performed in this place, hence making it harder and harder to produce nuanced and meaningful ethnographic research. Once I am officially defined as an outsider, it may become easier for those who object to my work to discredit me as irrelevant or even as a traitor. Simultaneously, this would likely bolster my credibility in certain circles. Being a formal outsider may also grant me physical access that I am denied as an Israeli citizen, namely access to Area A in the West Bank and maybe even to Gaza, as well as access to Palestinian academic institutions and possibilities for collaborations with Palestinian scholars.

I am still contemplating whether or not to renounce my Israeli citizenship. This, then, is my current liminal state of existence as a Jewish Israeli who wishes to continue studying and resisting the occupation both from the outside in and from the inside out. 